\title{
Juridical Analysis of Claim Rejection of Smartlingk Insurance Program: Flexi Account Plus And Critical Illness Plus At Pt. Allianz Indonesia Insurance Medan Branch
}

\author{
Alfindo Sebastian Putra Barus ${ }^{1}$, Emir Syarif Fatahillah Pakpahan ${ }^{2}$, Roswita Sitompul $^{3}$, \\ Dewi Ervina Suryani ${ }^{4}$ and Suhaila Zulkifli ${ }^{5}$ \\ \{alfindobarus.ab@gmail.com ${ }^{1}$ \} \\ Universitas Prima Indonesia ${ }^{12345}$
}

\begin{abstract}
The legal relationship between the parties in the insurance agreement is the customer as the insured and the insurance company as the insured, the rights and obligations are set forth in the form of a policy and explain the premium. In insurance practice, not all claims submitted by the insured are accepted, while the criteria for rejection of customer claims by the Allianz company include: Completeness of claim documents; Exceeds the predetermined time; Claims are not covered by the agreement; Before the policy was purchased the disease already existed; Exceptions in filing a claim; and Breaking the law; Insurance claim dispute settlement can be carried out by the Financial Services Authority. The insurance policy contains clauses on how to resolve disputes, such as deliberation, arbitration or court. In addition, disputes can be resolved through dispute resolution institutions such as the Consumer Dispute Resolution Agency (BPSK) and the Indonesian Insurance Mediation Agency.
\end{abstract}

Keywords: Insurance, Insurer and Insured

\section{Introduction}

Humans living life and performing activities are faced with the possibility of uncertainty, in the form of events that cause a sense of insecurity called risk [1], Derived from economic factors, natural factors, or human factors. This risk poses a burden of loss to property or the human soul itself. Human life planning is inseparable from insurance or coverage which is a translation of Inkriesurance or assurantie, arising from human needs [2]. Insurance as an act of planning future life that is preventive (preventive). Human beings as beings of God are endowed with the advantage of having the ability to seek efforts to overcome insecurity, from uncertainty to a certainty, so that they can avoid or overcome risks, either individually or collectively. Attempts to overcome natural nature manifest as a state of uncertainty, things that man does to avoid or pass it on to others outside himself [3]. Transfer of insecurity or a risk is done to the insurance company. Insurance companies openly offer a protection or protection against an event that will pose a risk, to both individuals and groups on the possible risk of loss by paying premiums.

Insurance is a growing industry in society. Public awareness of the importance of protection against various risks that may occur at any time is one of the reasons for the high number of people using insurance products [4]. The insurance company acts as a risk bearer in conducting 
business in connection with the insured or through an insurance broker. Insurance companies are non -bank financial institutions in the field of financial services to the public in overcoming risks that occur in the future [6]. Insurance does provide many benefits to the community, but insurance is something that is reluctant to follow because of problems regarding the settlement of claims that are difficult and convoluted by the insured or the beneficiary's heirs. Fulfilment of insurance claims is an obligation of the insurer, this is a consequence of the implementation of the agreement as Article 1234 of the Code of Civil Law (KUHPdt), which states that each agreement is to provide something, to do something, or not to do something.

In the context of an insurance agreement, the subject is an agreement to do something. For the insurer, it is the promise of the insurer to provide compensation for loss or loss or liability arising or legitimate insurance benefits [7]. Settlement of claims that are considered difficult and convoluted without any mistakes made by the insured is a proof that the rights of the insured/heirs have been violated by the insurer.

Article 276 of the Commercial Law (KUHD) has regulated the insurance company to compensate for losses suffered by the insured in the event of an event or event without prior knowledge or outside the power of the insured, no loss or damage due to the fault of the insured himself, charged on insurer. In fact, he can still hold or collect the premium, when he has begun to bear the danger. In addition to the provisions in the KUHD on the obligation to settle claims, also regulated in Article 26 paragraph (1) letter d of Law Number 40 of 2014 on Insurance, states: Insurance companies must meet standards of business conduct which include provisions on: settlement of claims. But in the fact that the settlement of claims by the insurer becomes a problem experienced by the consumer, so that only the party who pays the obligation without accepting what is his right. The insurance company as the party that provides protection and protection must provide a compensation in the form of insurance money to the heirs or family insured.

The insurer in terms of fulfilling an obligation must be based on correct facts, a medical certificate on the cause of death of the insured becomes a fact for the insurer in accepting or rejecting a claim, so that PT. Alianz Insurance in Medan analysed all claim filing documents as well as medical search results, it is known that:

1. Medical record (alm) had a history of stays in November-December 2012 with a diagnosis: ischemic stroke, physical examination: hemiparese sinistra + hyperuricaemia + obesity. CT scan results: subacte ischaenia cerebral infarction in the right basal ganglia, chronic ischaemia cerebral infarction in the right radiate corona, and subcortical lobe of the left occipitalis.

2. Medical record (alm) had a history of stay in May 2016 with complaints: swelling of the lower stalk +/- 3 days, blood pressure 150/90 mmHg, diagnosis: CHF ec CAD, ischemic stroke, physical examination: hemiparese sinistra + hyperuricaemia + obesity. CT scan results: subacte ischaenia cerebral infarction in the right basal ganglia, chronic ischaemia cerebral infarction in the right radiate corona, and subcortical lobe of the left occipitalis.

3. Medical record (alm) had an ECG examination in May 2016 with the results: AF ec DD, Ishaemic lateral. Medical record (alm) once performed a thorax examination in May 2016 with the result: cardiomegaly due to RAN and LAH. Seta some other diseases suffered by (alm) which is very unfortunate the data of the diseases suffered were not submitted in writing in the Life Insurance Application Letter signed by (alm) on September 8, 2016.

In the life insurance application letter regarding the health statement of the prospective insured (alm) never stated that he was diagnosed /suffering from a disease and yes, he stated that he was healthy and told the truth and honestly. As a result of the error, it will result in the rejection of an insurance claim of the insured's heirs, because the insurer considers that there is a discrepancy between the information contained in the Life Insurance Request Letter (SPAJ) 
with the facts of the insured's death. In this case the insurer assumes that there is a bad faith done by the insured at the time of closing the insurance agreement. If observed, the rejection of the claim by the insurer caused by an error (alm) in providing a certificate of application for life insurance. Legislation has regulated the maintenance of good and correct medical records, but the insurer is still unwilling to meet its performance to pay the insurance money so that the heirs suffer losses.

The principle of good faith in every agreement must be upheld, including the insurance agreement in order to enter into an agreement that benefits each other to the parties. Efforts to fight for the right to obtain payment for claims made by the insurer, then human beings as gods who are given the advantage, will think to find an institution that can help solve the problems faced. The complaint was caused because the insurance company as his father's insurer did not fulfill the obligation to pay the insurance fund on the death of the insured. the arrival of the heir to file a complaint about the material loss suffered due to non -disbursement of insurance money (alm) from an insurance company, namely PT. Allianz Medan.

The heirs feel harmed due to the injury of the promise (default) of PT. Allianz Medan who did not meet the performance as promised. PT. Allianz Medan is of the opinion that it has no obligation to perform the achievement of paying insurance money for the death of the insured on the grounds that the insured has bad faith in entering into the insurance agreement. The action is evidenced by a medical certificate on the cause of death of the insured from the hospital that conducted the examination before the insured died on December 16, 2014. The death certificate states the cause of death of the insured was due to high blood pressure and stroke. There is a discrepancy between the statement of incurred pour in the SPAJ found in the police with the death certificate issued by the hospital. Based on these facts, the insurer rejects the insurance claim filed by the insured's heirs.

After re -examination by the insured's heirs to the hospital, the heirs obtain the fact of the patient's death certificate stating that the insured died due to stroke and high blood pressure is mistaken. Confusion due to insured medical records (Alm). Medical record is the basis in making a medical certificate of death of the patient, so that the death certificate is also wrong/mistaken. In fact, it belongs to the insured, providing clarification to the heirs that there has been an error in the life insurance application letter. The heirs also filed a defense to the insurance company on the rejection by bringing a letter of clarification that there had been an error regarding the cause of death. that the insured's death occurred suddenly without being caused by a particular disease, regarding stroke and high blood pressure it belonged to another patient.

The insurance company as the insurer even though it has received a letter of clarification from the Hospital that the first death certificate issued is wrong. However, it still rejects the heir's insurance claim by adhering to the first insured's death certificate. Due to the losses suffered, the heirs filed a complaint to the Medan Regional Financial Services Authority as an institution that conducts supervision in the insurance sector.

Based on the background, a research was conducted on the Juridical Analysis of the Rejection of Claims of SmartLingk Insurance Program: Flexi Account Plus and Critical Illness Plus at PT. Allianz Indonesia Insurance Medan Branch.

\section{Problem Formulation}

1. How is the SmartLingk insurance program agreement: Flexi Account Plus and Critical Illness Plus at PT. Allianz Indonesia Medan Branch Insurance with customers?

2. How is the rejection of claims and settlement of the rejection of claims of SmartLingk 
insurance program: Flexi Account Plus and Critical Illness Plus at PT. Allianz Indonesia Insurance Medan Branch?

\section{Research Methods}

In research, appropriate methods are required and appropriate to the type of research conducted as well as systematic and consistent. The method in this study is empirical juridical. The empirical juridical approach is a problematic approach regarding matters of a juridical nature and the fact of the implementation of life insurance claims in PT. Alianz Medan branch. Empirical law research or sociological research is legal research that uses primary data [8]. According to the empirical approach is based on facts obtained from research and observation [9]. The research is conducted based on scientific methods that are part of the empirical approach. The research is also based on legal theory, the provisions of applicable laws and regulations as well as the opinions of scholars and experts.

\section{Results and Discussion}

Smartlingk Insurance Program Agreement: Flexi Account Plus and Critical Illness Plus at PT. Allianz Indonesia Medan Branch Insurance with Customers. Article 1 number 1 of Law Number 40 of 2014 states that insurance is an agreement between two parties, namely the insurance company and the policyholder. Furthermore, Article 6 of Law Number 40 of 2014 on Insurance Business states that insurance companies must have hundreds of legal entities in the form of limited companies, cooperatives or joint ventures. While Article 1 number 22 of Law Number 40 of 2014 states that the policy holder is a party who finds himself under an agreement with an insurance company, sharia insurance company, reinsurance company, or sharia reinsurance company to obtain protection or risk management for himself.

The policyholder or insured can have the status of an individual, association or legal entity, whether corporate or non -corporate, however, most importantly the insured has the status of the owner or interest in the property in the insurance agreement. The insurer is the party who bears the losses that may occur to the insured. However, the understanding of loss should not cause the financial position of the insured to be more profitable than the position before suffering the loss, which means only returning to the initial position of the insured.

The legal relationship between the insured and the insurer will occur from the occurrence of the insurance event. An insurance event is a legal act in the form of an agreement or free agreement between the insurer and the insured regarding the object of insurance, an uncertain event (event) that threatens the object of insurance and the conditions that apply to insurance. The agreement or agreement is expressed in written form in the form of a deed called the police. The police are a tool of evidence used to prove that an insurance agreement has taken place. Emmy Pangaribuan stated the police were perfect proof of what they had promised in the police [10].

Once the insured and the insurer have entered into an insurance agreement, the insured is willing to provide a number of premiums that are obligatory and entitled to receive compensation for possible losses later, otherwise the insurer is entitled to receive premiums from the insured and is obliged to bear the losses that may occur. later but the premium paid by the insured remains the insurer in the absence of uncertain events (events). The insurance 
relationship between the insurer and the insured is a legally bound bond that arises or an independent agreement.

Insurance is a bilateral agreement between the insurance company and the policyholder. In the agreement, it must meet the legal requirements of the agreement, namely agreement, competence, certain things and a lawful reason, as specified in Article 1320 of the Criminal Code. Only in addition to the legal requirements of the agreement, in insurance there are still other special requirements regarding the payment of premiums in Article 246 of the KUHD and the notification obligations set out in 251 of the KUHD.

Article 1233 of the Criminal Code states that the source of the alliance is the agreement and the law. An alliance can arise or originate from 2 (two) things, namely laws and agreements. In an alliance due to law, the birth of an alliance without taking into account the will of the parties in the alliance, the will comes from the lawmaker, while the alliance due to the agreement because the parties want and are aimed at certain legal consequences (which they want). The insurance agreement occurs immediately after the agreement is reached between the insured and the insurer, reciprocal rights and obligations arise from then on, even before the policy is signed.

That the agreement is a legal relationship between two parties that contains rights and obligations. In an insurance agreement, each party has rights and obligations in carrying out the agreement, but the insurance agreement has a special nature. These rights and obligations can be deduced from the provisions in the KUHD and the insurance agreement (policy).

1. Rights of the Insured

a. Require that the police be signed by the insurer as stated in Article 259 of the KUHD, which reads: If a lien is closed directly between the insured, or a person whom he has ordered for it or has authority for it and the insurer, then the police must within 24 hours after requesting it be signed by the latter, unless in the provisions of the law in a particular case a longer period is stipulated.

b. Demands that the police be immediately handed over to the insurer, as stated in Article 260 of the KUHD, which reads: When the insurance is closed through a broker, the signed police must be handed over within eight days after the closing of the agreement.

c. Seek compensation to the insurer for negligence in signing and handing over the police so as to cause loss to the insured, as stated in Article 261 KUHD, which reads: If there is negligence, in matters specified in the previous two articles, then the insurer or broker must the insured compensates for the losses that may arise from the negligence.

d. Through the court, the insured may release the insurer from all obligations in the future, as stated in Article 272 of the Criminal Code, which reads: If the insured, by a notice through the court, relieves the insurer of all obligations for the future, then he may for the same time and the same danger, once again underestimating its interests. In that case, then for the threat of annulment in the new police must be mentioned both the old coverage and the notification through the court above.

e. Demand the refund of restono premiums, either in whole or in part, if the insurance agreement is void or void, as stated in Article 281 of the Criminal Code, which reads: In all cases where the insurance agreement in whole or in part falls or becomes void, while the insurer is required to return the premium for the whole, or for such part as for which he has not been in danger.

f. Claims damages to the insurer if the events agreed in the police occur.

2. Liabilities of the Insured

a. Pay a premium to an insurer, as stated in Article 246 of the KUHD, which reads: Insurance or indemnity is an agreement, by which an insurer binds to an insurer, by 
receiving a premium, to compensate him for a loss, damage or loss of profit that expected, which he may suffer due to an indefinite event.

b. Provide true information about the insured object, as stated in Article 251 of the KUHD, which reads: Any information that is false or incorrect, or any non-disclosure of things known to the insured, no matter how good etiquette is on it, as such, so that if the insurer had known the true circumstances, the agreement would not have been closed or not closed on the same terms, resulting in the void of coverage.

c. Trying or preventing events that could cause loss to the insured object do not occur or can be avoided (Article 283 KUHD).

d. Notify the insurer if an event has occurred that befell the insured object, following its preventive efforts.

3. Rights of Insurers

a. Demand the payment of premiums to the insured in accordance with an agreement, as contained in Article 246 of the KUHD, which reads: Insurance or indemnity is an agreement, by which an insurer obligates himself to a dependent, by receiving a premium, to compensate him for a loss, damage or loss of expected benefits, which he may suffer due to an indefinite event.

b. Request true and complete information relating to the insured to him, as stated in Article 251 KUHD, which reads: Any information that is false or incorrect, or any nondisclosure of things known to the insurer, no matter how good the ethics of it, which such is its nature, that, if the insurer knew its true circumstances, the agreement would not have been closed or not closed on the same terms, resulting in the void of cover.

c. Have a premium and even claim it in the event that the promised event occurs for the fault of the insured, as stated in Article 276 of the Criminal Code, which reads: No loss or damage caused by the fault of the insured himself shall be borne by the insured himself shall be borne by the insurer. In fact, the insurer has the right to have a premium or claim it, if he has begun to bear a danger.

d. Doing reinsurance (reinsurance) to another insurer, as stated in Article 271 of the KUHD, which reads: The insurer has the power to once again insure what he has insured.

4. Obligations of the insurer

Sign the police and hand it over to the insured, as stated in Articles 259 and 260 of the KUHD, which reads:

a. Article 259: If an indemnity is closed directly between the insured, or a person whom he has ordered or has authority to do so and the insurer, then the police must within 24 hours after requesting it to be signed by the latter party, unless in the provision- the provisions of the Law in a particular case stipulate a longer term.

b. Article 260: If an insurance is closed through a broker, then the signed policy must be submitted within eight days after the closing of the agreement.

c. Provide compensation to the insured, if the agreed event occurs, as stated in Article 246 of the KUHD

d. Return the restoration premium to the insured, if the insurance is cancelled or falls, as stated in Article $281 \mathrm{KUHD}$, ie in all cases where the insurance agreement for all or part falls or becomes void, while the insured has acted in good faith, then the insurer is required to return his premium for the whole, or for such part for which he has not been in danger. 
In the era of globalization, the growth of the industrial world is accelerating, can be seen from the many standing various types of industries, both in the field of manufacturing and services. So that it causes such tight competition in marketing the products/services they offer to consumers. Competition is one of the common things faced by every company in conducting business activities. One of the keys to success in winning the competition of the business world is by providing a level of performance to customers, such as providing products with better quality, cheaper prices, faster product delivery and better service than competitors. Because products with poor quality, expensive prices, slow delivery, and poor service can make customers disappointed. According to American Customer Satisfaction, the Performance Level Index is an indicator for companies to evaluate the company's past, present and future performance. Exit Voice Theory says that the consequence of a rapid increase in customer satisfaction is a decrease in customer complaints and an increase in customer loyalty.

As one of the insurance services companies, PT. Allianz Life Assurance feels the need to increase competitiveness, one of which is by improving the quality of services. In an effort to improve the quality of service, the company wants to know the customer's assessment of service performance. Therefore, the company needs to conduct research on measuring the level of service performance, in order to know the extent to which customer expectations are met on the company's performance that has been done so far, this customer can be used as input or feedback in improving the quality of existing services.

The definition of life insurance is a risk shifting of money (financial lost) by the insured to the insurer. Loss of money (financial lost) as a result of death, total permanent disability or partial permanent disability can lead to the loss of a person's economic value, because the economic value is equal to a person's income capacity. A person's economic value can be measured even though it is relative, while social and religious values cannot be measured. Those most interested in economic value are the man himself, wife/husband, children and family.

The role (benefits) of life insurance in human life is to anticipate future risks caused by the uncertainty (unpredictable) of the future, protect themselves from financial loss due to such possibilities, and as an alternative investment with economic protection guarantees. SmartLink Flexi Account (SFA) is an insurance product with a lifetime coverage (100 years of coverage) that provides investment options to policyholders. SmartLink Flexi Account premiums are paid regularly up to the age of 99 years. The small size of the cost allocated for protection is calculated every month. The cash value of the SmartLink Flexi Account is calculated from the number of investment-link units that have been accumulated each year. The value of each unit is calculated based on unit pricing performed once a week, ie Monday and announced in Bisnis Indonesia.

Death benefit will be given at $100 \%$ of the sum insured plus the value of the investment and paid at once. When this insurance has been paid then the policy will end. This insurance comes into effect on the date stated in the policy and the first premium has been paid in full. Claim Rejection and Settlement of Claim Rejection of SmartLingk Insurance Program: Flexi Account Plus and Critical Illness Plus at PT. Allianz Indonesia Insurance Medan Branch. A claim is a performance of a promise, made by the insurer at the time of entering into a contract [11]. A claim contains a demand for acknowledgment of a fact that one is now entitled (to own or have) something [12].

The meaning of the claim is shared [13]:

1. Types of claims:

a. Maturity claim

In a maturity claim, the police holder survives until the police contract expires, that is, until the due date. 
b. Early claim

Life insurance companies do not expect death from the insured within three years of the inception of the policy. These unsolicited claims are also called Early Claims

c. Death Claim

A death claim occurs when the insured dies at the time of police protection.

\section{Survival Benefits}

Survival benefits can be paid before the due date but only for up to a certain period. Examples: periodic payments under withdrawals and bonuses or loyalty additions

3. Claim requirements [14]:

a. Is the police still going on

b. Whether the premium has been paid

c. Whether the loss is due to the risk incurred

d. How much is insured is affected by the loss

e. Loss records submitted without delay are not required.

4. Notice of Claims

It is a communication process between the insurer and the insured when a claim arises. Generally, the insurance company's agent gives a small booklet to his client that explains what to do in the event of a loss. The main idea is to inform the insurance company that a loss has occurred. In a soul company, notification to the agent can be made by telephone, fax, letter, Email, and the agent will process the claim. While health insurance, often the settlement of claims is carried out through the Hospital or Doctor.

a. Notification of Claims Due

The police endowment pays the claim due on the condition the insured is the actual police holder with police proof, the premium has been paid in full, submits the original police (letter of loss if missing police).

b. Grant of Died Claims

Paid only when the insured dies within the term of the police contract notified by the designated heirs in writing. The notice includes: Policy number, name, date of death, cause of death, relationship with the insured.

c. Insurer's initiative in the claim process

The insured must immediately report his losses to the insurance company or his agent legally, the insured does not fulfil his reporting obligation when he has notified the agent.

5. Claim Settlement Procedure:

Insurers use a variety of ways or means to obtain a satisfactory settlement of losses.

Whoever or any type of organization is given the responsibility to settle the loss, but the steps taken to achieve the settlement of the claim, namely [15]:

1. Check insurance coverage

If a notification of loss has been received by the agent, then an inspection of the facts is conducted to determine whether the insurance company needs to follow-up (take further action). There are several questions that arise and must be answered with "YES" if the settlement of the loss is to be processed:

a. has a police force been issued for him and whether the police are still in place;

b. whether the loss is due to an insured disaster;

c. whether the loss of the property was borne by the police;

d. whether the loss claimed is the type of loss covered by the contract/police;

e. is the claimant (who makes the claim) the person entitled to receive payment;

f. did the loss occur in the place covered by the contract. 
Each of the above questions must be answered based on the facts submitted by the claimant. If at the time of inspecting each of the above questions, the insurer is confident of the basis for the claim, then the claimant is sent a proof of loss form. If the insurance company obtains the claim does not meet one of the basic requirements above, then the claim settlement process is not continued.

2. Investigating Claims

To determine the obligations to the claimant, a more complete investigation is needed, including:

a. Ensure that indeed the facts submitted in the proof of loss.

b. Determine whether the insured's action cancels the claim. Whether the insured action fulfils the obligations stated in the insurance contract

c. Determine the amount of loss

d. When the insured has reported the amount of loss, then the adjuster will examine the claim and compare it with his own assessment of the amount owed to the insured based on the police. If this amount does not match, the adjuster will explain to the insured how he came to the estimate. The insured will also explain the calculation to the adjuster. They can arrange a satisfactory solution for both parties concerned.

c. Prepare proof of loss

As soon as the investigation is completed, and if nothing turns out to invalidate the insured's claim. The loss settlement process may require the adjuster (claim settler) to determine, whether the insurance company can recover some of the money already paid for the claim. Salvage (rescuer) occurs when part of the damaged property can be sold by a representative (representative) of the insurance company on behalf of the insured or insurer.

In the practice of insurance, not all claims submitted by the insured are accepted, the criteria for rejecting claims between customers and Allianz companies include:

1. Completeness of claim documents.

Completeness of documents is one of the conditions accepted for the submission of insurance claims. Prior to filing a claim, the completion of all documents is required because if the policyholder lacks one claim filing document, then the insurer will not accept the filing. When filing a life insurance claim, in filing a claim, a certificate from a doctor is usually required as well as filling out a claim form. When filling out a form, honesty is essential. Allianz requested to complete a medical record. According to Permenkes Number 269/MENKES/PER/III/2008, a medical record is a file containing records and documents, including the patient's identity, examination results, treatment provided, and other actions and services to patients. The hospital never allowed to provide complete medical records for violating Permenkes Number 269/Menkes/PER/III/2008. While Allianz still refused the payment of customer claims on the grounds of not meeting the provisions in the policy agreed by them. On the case of the rejection of the claim to the customer, the PT. Allianz also violated Article 62 of Law Number 8 of 1999 on Consumer Protection.

Article 19 Regulation of the Financial Services Authority Number 23/POJK.05/2015:

a. The insurance policy must be clearly written so that it can be easily read and understood by the policyholder, insured, or participant.

b. In the case of an insurance policy there is a formulation that can be construed as:

- Exclusion or limitation of the cause of the risk covered under the relevant insurance policy; and/or

- Reduction, restriction, or waiver of company liability, the formulation section in question must be written or printed in bold or italics so that it can be easily identified 
the exclusion or limitation of the cause of risk or the reduction, limitation, or waiver of company liability.

2. Exceeding the specified time.

The insurance company always gives a certain time limit when filing a claim, if the policyholder exceeds the prescribed time limit then the filing of a claim can be delayed or even rejected. In general, the deadline for filing a car or motorcycle claim is usually only 3 x 24 hours and for life insurance, the deadline is between 30 to 60 days.

3. Claims are not covered in the agreement.

The insurance policy contains any clauses or agreements that are included and not in the insurance company's liability. For example, it can be taken from health insurance, in the insurance of hospitalization time requirements to be claimed Insurance such as 24 -hour hospitalization provisions. If the policyholder must be hospitalized, but if the time is still less than 24 hours, then the insurance claim cannot be filed and if filed will be rejected because it has not reached the provisions of the time required by the insurer.

4. Before the police bought the disease was already there.

At the beginning of the purchase of a policy, it is best that the buyer of the policy is honest when filling out the form and being asked questions by the insurer about the illness that has been experienced. Because if the policy buyer is proven to be hiding a pre -existing illness when filing a claim, the insurer will not accept the claim even though the waiting period has passed. This is related to the good faith of the insured is regulated in Article 251 of the KUHD which states: Any information that is false and incorrect, or any non-disclosure of things known to the insured, no matter how good faith he has, which is such that, if the insurer having known the actual circumstances, the agreement will not be closed or will not be closed on the same terms, resulting in the void of coverage.

5. Exceptions in filing claims.

The insurance company regulates anything that is covered by insurance and also regulates in case of exclusions. Exclusion means things that are not included in the insurance coverage. Examples that can be taken from life insurance are death due to suicide, criminal acts, and court sentences.

6. Breaking the law

Insurance policies are always compliant with applicable law, so it will not be possible for insurance to accommodate events because it is not a violation of the law. Because if it is proven that the policy holder has violated the law, the submission of a claim made to the insurer will be rejected. Holders of health insurance policies when suffering serious injuries also cannot file a claim, because the serious injuries are the result of being beaten by the masses for committing a crime.

Violation of the principle of good faith is not necessarily the fault of the insured, if the insured does not know the illness he is suffering from, it is the insurer's obligation to check the insured's health. So that if there is a problem with the health of prospective insurers who do not qualify, the police can be prevented. In addition, the giving of false information by the insured or bad faith such as fraud by the insured can be known. In addition to denials caused by breach of good faith or misrepresentation of information, denials of claims are usually caused by non compliance with the provisions of the insurance policy [16].

Insured or policyholders should avoid things that make an insurance claim rejected, as there are many reasons why a claim can be rejected. studying and understanding the contents of the policy is the best way to avoid the rejection of insurance claims [17]. A life insurance agreement can only take place when the policyholder has an interest in the life of the person 
whose life is insured and cannot seek profit by insuring the insured's life. If that happens then the life insurance agreement will be void for the sake of the law [18].

Regarding insurance claims are regulated in several regulations, namely Article 23 paragraph (1) of Government Regulation of the Republic of Indonesia Number 73 of 1992 as amended by Government Regulation Number 39 of 2008 on the second amendment to Government Regulation Number 73 of 1992 edited as follows: Insurance company or reinsurance company it is prohibited to take actions that may delay the settlement of payment of claims, or not to take actions, that should be taken that result in delays in the settlement and payment of claims.

That in the insurance agreement, then arise the rights and obligations of the parties known for the achievement. The existence of default gives the victim the right to sue for damages on the basis of default to the District Court. Regarding the form of compensation on the basis of default can be in the form of compensation of costs, including costs that have been incurred, the actual losses have been suffered and profits that have been calculated or imagined will be obtained if there is no default [19].

Insurance is a business based on trust between the insurance company and the customer, but sometimes disputes arise. In life insurance, disputes are generally whether a claim is rejected or accepted [20]. In general insurance, disputes can also arise solely about the number of claims while the validity of a claim has been acknowledged by the insurer [21].

To resolve a dispute between the insurance company and the customer, can refer to the provisions in the insurance policy listed in the clause how to resolve disputes that arise. Disputes that occur can be resolved through several means, such as deliberation, arbitration or court [23]. In addition, disputes can be resolved through dispute resolution agencies such as the Consumer Dispute Resolution Agency (BPSK) and the Indonesian Insurance Mediation Agency.

\section{Civil Lawsuit in the District Court}

Insurance policies often contain clauses for resolving disputes through the courts, which often burden the customer even to the point of diminishing the customer's intention to seek justice. This is because the settlement of disputes in court costs uncertain and the settlement process is quite long since the District Court, then the appellate court may appeal to the High Court and if still dissatisfied will be decided at the level of cassation in the Supreme Court and maybe even at the level of Reconsideration. . If there is a dispute between the customer and the insurance company and in the insurance policy there is a clause for resolving the dispute through a court, then the customer must bring the dispute to Court. The legal basis that can be used by the customer is default (negligence or forgetfulness) on the implementation of the agreement as stipulated in Article 1243 of the Criminal Code. Against the default of the insurance company, the customer can claim compensation.

Compensation is often detailed in three elements: costs, losses, and interest [24]. The meaning of cost is all expenses or expenses that have been incurred by one party [25]. Meanwhile, the term loss is a loss due to damage to goods belonging to the creditor due to the negligence of the debtor [26]. Related to the term interest which has a definition is a loss in the form of loss of profit, which is already imagined by the creditor [27].

\section{Bankruptcy in the Commercial Court}

The issue of debts between the insured to the insurance company can be resolved through bankruptcy law efforts. The existence of this bankruptcy is based on a violation of the lendingborrowing agreement between the debtor and creditor. This bankruptcy application is filed due 
to a default action taken by the debtor to repay his debt to the creditor. Creditors who feel harmed as a result of the debtor's default action file for bankruptcy to the Commercial Court.

Pursuant to Article 1 number 1 of Law Number 37 of 2004, bankruptcy is a general seizure of the wealth of a bankrupt debtor whose management and settlement is carried out by a Curator under the supervision of a Presiding Judge as stipulated in this law. Bankruptcy law enforcement can be defined as a process of management and settlement of the debtor's remaining assets as a whole for the repayment of debts of creditors. The debtor as the owner of the property is not entitled to make all efforts to manage and transfer ownership of the property to others. However, the curator will perform the task of managing and disposing of the debtor's wealth. This can of course be done after a bankruptcy decision from the Commercial Court.

The bankruptcy application can be filed and adjudicated by a commercial court, if it meets the requirements of Article 2 paragraph 1 of Law Number 37 of 2004. Based on Article 2 paragraph 1 of Law Number 37 of 2004, the bankruptcy requirements are: Debtors who have two or more creditors and failing to pay off at least one debt that has fallen due and can be collected, is declared bankrupt by decision. Court.

Insurance companies reviewed from the bankruptcy requirements can be filed for bankruptcy by the insured. This can be done if the insurance company fails to pay the insured. Bankruptcy applications cannot be filed by debtors against certain debtors. Bankruptcy applications that cannot be filed by debtors are bankruptcy in the public interest, bank debtors, securities company debtors, Clearing and Guarantee institutions, Depository and Settlement Institutions, and insurance company debtors, reinsurance, pension funds or State -Owned Enterprises in the public interest.

This is regulated in Article 2 paragraphs 2 to 5 of Law Number 37 of 2004, namely: (2). The application as referred to in paragraph (1) may also be filed by the Prosecutor's Office for the public interest. (3). In the case of the debtor is a bank, the application for a bankruptcy statement can only be submitted by Bank Indonesia. (4). In the event that the debtor is a stock company, stock exchange, skewed institution and Guarantee, Depository and Settlement Institution, the application for bankruptcy can only be filed by the Capital Market Supervisory Agency. (5). In the case of the debtor is an insurance company, reinsurance company, Pension Fund, or State -Owned Entity operating in the field of public interest, a bankruptcy declaration application can only be submitted by the Minister of Finance.

The existence of Article 2 paragraph (5), insurance and reinsurance companies can no longer be bankrupt directly to the Commercial Court by the debtor. However, the bankruptcy application must be submitted to the Minister of Finance. The presence of this article can give rise to a different perspective between the government and the public in the assessment of bankruptcy declarations.

The Legislator seeks to make Article 2 paragraph (5) of Law Number 37 of 2004, as follows: The requirement for a bankruptcy statement submitted to the Minister of Finance is to ensure that the bankruptcy application filed against the insurance company is really a bankruptcy application that has been meet the bankruptcy requirements referred to in the Bankruptcy Law. That is, as long as the Minister of Finance assesses that the requirements are met and does not see the effort or ability of the insurance company to resolve them, the Minister of Finance must file a bankruptcy application to the commercial court, because the commercial court is the only institution that can examine and decide bankruptcy and Deferment applications. Debt Payment Obligations [28].

This legal dispute can occur between the government and the public, if the Minister of Finance rejects the bankruptcy application of the debtor against the insurance company. Debtors can certainly think that the government is impartial towards the community, especially debtors 
who are disadvantaged. This opinion is based on the statement of Ricardo Simanjuntak, lawyer and legal expert, namely: Unfortunately, in the society of insurers, the above understanding is not properly understood, because there are still many insurers who translate the presence of Article 2 paragraph (5) of the Bankruptcy Law as article stating that insurance companies are immune from bankruptcy.

If this is the understanding of the insurance community, or also the insurance authority, then the presence of Article 2 paragraph (5) is also counterproductive and tends to create potential disputes and distrust of the insurance community in Indonesia. If the authority enters into the attitude of rejecting the entire bankruptcy application against the insurance company submitted to it, there will be two possibilities; first, the rejection can be resisted from the side of Administrative Law by filing a lawsuit to PTUN against the Minister of Finance by the bankrupt petitioner, and the attitude of the rejection on the other hand will make unintentional perpetrators more free to roam, will hide behind authority if consumers who he was disappointed to take bankruptcy legal action against him [29].

The government needs to address the issue of insurance bankruptcy well by paying attention to the public interest of the community, especially debtors. In addition, it is necessary to disseminate the application of this article to insurers so as not to create a legal dispute. The dissemination prioritizes the public's understanding that the issue of the debts of the insurance company can still be examined and decided by the Commercial Court, although the filing by the bankruptcy applicant must be done through the Minister of Finance.

\section{Settlement Through Consumer Dispute Resolution Bodies}

The Consumer Dispute Resolution Agency (BPSK) is a body responsible for handling and resolving disputes between business actors and consumers. The establishment of BPSK itself is based on the tendency of people who are reluctant to speak in court. This is due to the imbalance in the position of consumers who are socially and financially unbalanced with business actors [30]. BPSK is an alternative dispute resolution agency outside the general judiciary. BPSK is given the authority set forth in Law Number 8 of 1999 to handle and resolve disputes between consumers and business actors, namely through mediation, conciliation, or arbitration. The choice of dispute resolution is left to the agreement between the consumer and the business actor. In addition, both parties are also given the freedom to choose and determine the panel of judges in examining consumer disputes. There are three juries that handle consumer disputes that consist of elements of consumers, business actors, and government representatives.

BPSK is adopted from the Small Claims Tribunal model which is in the potential stage of being the preferred consumer dispute resolution option [31]. These potentials adopted from the Small Claims Tribunal include: BPSK bridges the simple and flexible ADR (Alternative Dispute Resolution) mechanism with an authoritative Court mechanism [32]. There is a balanced combination of the three elements (Consumers, Business Actors and Government) in BPSK. This is of course a force in reconciling conflicts of interest [33]. BPSK also functions as a Quasi Court Plus due to the adjudication and no adjudication functions in BPSK.

\section{Indonesian Arbitration Mediation Agency (BMAI)}

Insurance claim disputes between the customer (insured) and the insurance company (insurer) often occur. For life insurance, the most disputed issue is due to the insured's lack of honesty in filling out the insurance request form, especially in relation to the insured's health history. Until after death, it is known that the insured is suffering from a disease that is not actually covered by insurance. As for general insurance, usually disputes that arise are about 
unpaid premiums, police guarantee that do not cover the incident, and the object of coverage that has been transferred to another party.

So far, the issue of claim disputes has been resolved by the government through the Ministry of Finance. However, in the presence of the Insurance Mediation Agency (BMAI), the settlement of the claim was submitted to BMAI. In other words, BMAI becomes an out -of court institution trusted to resolve insurance disputes.

The Indonesian Insurance Mediation Agency is an independent and impartial institution that provides services for resolving disputes between the Insurance Company and the Insured [34]. The establishment of BMAI was initiated by the Government and all Indonesian Insurance Company Associations (FAPI) namely the Indonesian General Insurance Association (AAUI), the Indonesian Life Insurance Association (AAJI) and the Indonesian Social Insurance Association (AAJSI) with the aim of providing more professional and transparent services based on satisfaction and protection as well as enforcement of customer rights [35]. BMAI was officially established on May 12, 2006 and commenced operations on September 30, 2006 [36].

Although BMAI is an insurance claim dispute resolution agency, not all disputes can be brought to BMAI. One of the reasons is because the power given to BMAI is still limited. With the limitation of BMAI's power in resolving insurance claim disputes, it is good before the insured brings the insurance dispute to BMAI, the insured pays attention to whether the dispute meets the conditions of the dispute can be brought to BMAI or not. The terms of the dispute brought to BMAI are:

a. Disputes with insurance claims of a maximum of Rp 500 million for general insurance and Rp 300 million for life insurance and social security insurance;

b. Disputes that have previously been attempted internally by the insurance company, but failed;

c. Disputes that do not involve the fixing of premium pricing, policies relating to interest rates and fees, actuarial standards and general provisions;

d. Disputes not related to criminal acts; complaints filed more than six months after the decision of denial by the insurance company.

e. Disputes that have not been resolved amicably;

f. The dispute is not a commercial dispute; and

g. The dispute has never been brought to court/arbitration or in the process of investigation by the authorities.

The dispute resolution process by BMAI consists of Mediation and Adjudication. The Mediation process begins with the receipt of a complaint report to BMAI. The complaint report will then be handled by the Case Manager. The Case Manager will endeavour to ensure that the insured and the insurance company can reach a settlement peacefully and fairly for both parties. In the event of a general dispute, the Case Manager will act as a mediator between the two parties. Furthermore, if the dispute cannot be resolved through mediation, then the dispute case will be brought to the adjudication level to be decided by the Adjudicator or Penal Adjudicator appointed by the BMAI.

\section{Arbitration}

An arbitration institution is a body chosen by the disputing parties to give a decision on a particular dispute, the body can also give a binding opinion on a particular legal relationship if a dispute has not arisen. Article 1 number 1 of Law Number 30 of 1999 is a method of resolving a civil dispute outside the general court based on an arbitration agreement made in writing by the disputing party. Basically, arbitration can take 2 (two) forms, namely [37]: 
1. The arbitration clause is contained in a written agreement made by the parties before the dispute arises (factum de compromitendo); or

2. A separate arbitration agreement after a dispute arises (Deed of Compromise).

Dispute resolution through arbitration has its limitations, as not all issues can be resolved through arbitration. Article 5 of Law Number 30 of 1999 regulates the scope of disputes that can be resolved through arbitration. Disputes that can be resolved through arbitration are only disputes in the field of trade and rights that according to law and regulation are fully controlled by the disputing party. This means that arbitration cannot be applied to issues within the scope of family law. Arbitase can only be applied to business problems. For entrepreneurs, arbitration is the most attractive option to resolve disputes according to their wishes and needs [38].

The arbitrage clause is widely used as a dispute resolution option in the civil field. The legal opinion given by the arbitration institution is in the form of a decision. The nature of this decision is binding. This is because the opinion given will be an integral part of the main agreement for which the opinion of the arbitration institution is sought. Violation of the opinion or decision of the arbitration means a violation of the agreement. Therefore, there can be no resistance in any form of legal action [39]. Arbitration decisions are independent, final and binding, so the Chairman of the court is not allowed to examine the reasons or considerations of the national arbitration decision.

\section{Conclusion}

The legal relationship of the parties in the insurance agreement is the customer as insured and the insurance company as insured, the rights and obligations in the agreement are set out in the form of a policy and explain the premiums. In the practice of insurance, not all claims submitted by the insured are accepted, the criteria for the rejection of customer claims by the Allianz company include: Completeness of claim documents; Exceeding the pre -determined time; Claims are not covered in the agreement; Before the police bought the disease was already there; Exceptions in filing claims; and Breaking the law; Settlement of insurance claim disputes can be done by the Financial Services Authority. The insurance policy contains a clause on how to resolve disputes, such as deliberation, arbitration or court. In addition, disputes can be resolved through dispute resolution agencies such as the Consumer Dispute Resolution Agency (BPSK) and the Indonesian Insurance Mediation Agency.

\section{References}

[1] Abdul Kadir Muhammad, Pokok Hukum Pertanggungan, Citra Aditya Bakti, Bandung, 1997.

[2] A. Hasyim Ali, Pengantar Asuransi, Bumi Aksara, Jakarta, 1993.

[3] Eman Suparman dan Endang, Hukum Asuransi: Perlindungan Tertanggung Asuransi Deposito Usaha Perasuransian, Alumni, Bandung, 1997.

[4] Emmy Pangaribuan, Hukum Pertanggungan, UGM, Yogyakarta, 1990.

[5] Junaedy Ganie, Hukum Asuransi Indonesia, Sinar Grafika, Jakarta, 2013.

[6] Mulhadi, Dasar-Dasar Hukum Asuransi, Raja Grafindo Persada, Jakarta, 2017.

[7] Ronny Hanitijo Soemitro, Metodologi Penelitian Hukum dan Jurimetri, Ghalia Indonesia, Jakarta, 2005.

[8] Ronny Kountur, Metode Penelitian Untuk Penulisan Skripsi dan Tesis, PPM, Jakarta, 2004.

[9] R. Subekti, Hukum Perjanjian, Intermasa, Jakarta, 2002. 
[10] Sri Rezeki Hartono, Hukum Asuransi dan Perusahaan Asuransi, Sinar Grafika, Jakarta, 2001.

[11] Suparman Sastrawidjaja, Aspek-aspek Hukum Asuransi dan Surat Berharga, Alumni, Bandung, 1997.

[12] W. J. S. Purwadaminta Kamus Besar Bahasa Indonwesia, Balai Pustaka, Jakarta, 1995.

[13] Sodiki, Ahmad. 2009. Konstitusionalitas Pemilihan Umum Model Masyarakat Yahukimo, Jurnal Konstitusi, Volume 6, Nomor 2.

[14] Asshiddiqie, Jimly. 2005. Demokrasi dan Hak Asasi Manusia, Delivered in studium general on The 1st National Converence Corporate Forum for Community Development, Jakarta, 19 December 2005.

[15] Arinanto, Satya, 2008. Hak Asasi Manusia dalam Transisi Politik di Indonesia, Jakarta: Pusat Studi Hukum Tata Negara Universitas Indonesia

[16] Arizona, Yance, 2009. "Hak Ulayat: Pendekatan Hak Asasi Manusia dan Konstitusionalisme Indonesia." Jurnal Konstitusi, Volume 6 Nomor 2, Juli 2009, Jakarta: Mahkamah Konstitusi

[17] Busroh, Abu Daud, 2008. Ilmu Negara, cetakan kelima, Jakarta: Bumi Aksara

[18] Bentham, Jeremy http://en.wikipedia.org/wiki/Jeremy_Bentham, accesed on 18 march 2010. Komisi Nasional Hak Asasi Manusia, tanpa tahun, Lembar Fakta HAM, Edisi III, Jakarta

[19] KomnasHAM. Noken dan Perempuan Papua, http://budayapapua.wordpress.com/2009/06/12/noken-dan- perempuan-papua/ accesed on tanggal 9 April 2021.

[20] Papua Pos, "Pemilu di Pedalaman Bisa Gunakan Noken", 20 Februari 2009

[21] Mahkamah Konstitusi Tokoh Ilmuwan dan Penemu, James Watt, http://www.ceritakecil.com/tokohilmuwan-dan- penemu/James-Watt-2, accesed on 18 march 2010.

[22] Aditama Setya Prakoso, Rinitami Njatrijani, Paramita Prananingtyas, Polis Asuransi Jiwa Sebagai Alat Bukti Penuntutan Klaim Dalam Perjanjian Asuransi Jiwa, Diponegoro Law Journal Volume 5 Nomor 3 Fakultas Hukum, Universitas Diponegoro, 2016.

[23] AIG Life, Pelatihan Sertifikasi Keagenan Bancassuree, Prosedur Klaim

[24] Budhy Budiman. Mencari Model Ideal penyelesaian Sengketa, Kajian Terhadap praktik Peradilan Perdata Dan undang-Undang Nomor 30 Tahun 1999.http://www.uika- bogor.ac.id /jur 05.htm.

[25] Dwi Tatak Subagiyo, Analisa Hukum Atas Penolakan Klaim Asuransi Kesehatan Dalam Kasus Antara Handoyo dengan Perusahaan Asuransi Allianz, Perspektif Volume XVII Nomor 3 Fakultas Hukum Universitas Wijaya Kusuma Surabaya, September 2012.

[26] Hilda Yunita Sabrie, Pembayaran Klaim Asuransi Jiwa Akibat Tertanggung Bunuh Diri, Jurnal Yuridika Volume 26 Nomor 1, Januari-April 2011.

[27] Kemana Membawa Sengketa Klaim Asuransi Jiwa, http://web.bisnis.com/edisi-cetak/edisiharian/keuangan/1id141378.html.

[28] Kiat Memilih Perusahaan Asuransi Jiwa, http://blog.keuanganpribadi.com/kiat- memilihperusahaan-asuransi.

[29] Ricardo Simanjuntak, Berbagai Sengketa Hukum Yang Dapat Muncul Dari Kontrak Asuransi Serta Penyelesaiannya, Jurnal Hukum Bisnis, Volume 28, Tahun 2007. 